\title{
Scenarios for greenhouse warming mitigation
}

\author{
Sørensen, Bent
}

Publication date:
1995

1995

Document Version

Publisher's PDF, also known as Version of record

Citation for published version (APA):

Sørensen, B. (1995). Scenarios for greenhouse warming mitigation. Roskilde Universitet. Tekster fra IMFUFA No. 300 http://milne.ruc.dk/ImfufaTekster/

\section{General rights}

Copyright and moral rights for the publications made accessible in the public portal are retained by the authors and/or other copyright owners and it is a condition of accessing publications that users recognise and abide by the legal requirements associated with these rights.

- Users may download and print one copy of any publication from the public portal for the purpose of private study or research. - You may not further distribute the material or use it for any profit-making activity or commercial gain.

- You may freely distribute the URL identifying the publication in the public portal.

\section{Take down policy}

If you believe that this document breaches copyright please contact rucforsk@kb.dk providing details, and we will remove access to the work immediately and investigate your claim. 


\section{Bent Sørensen}

3

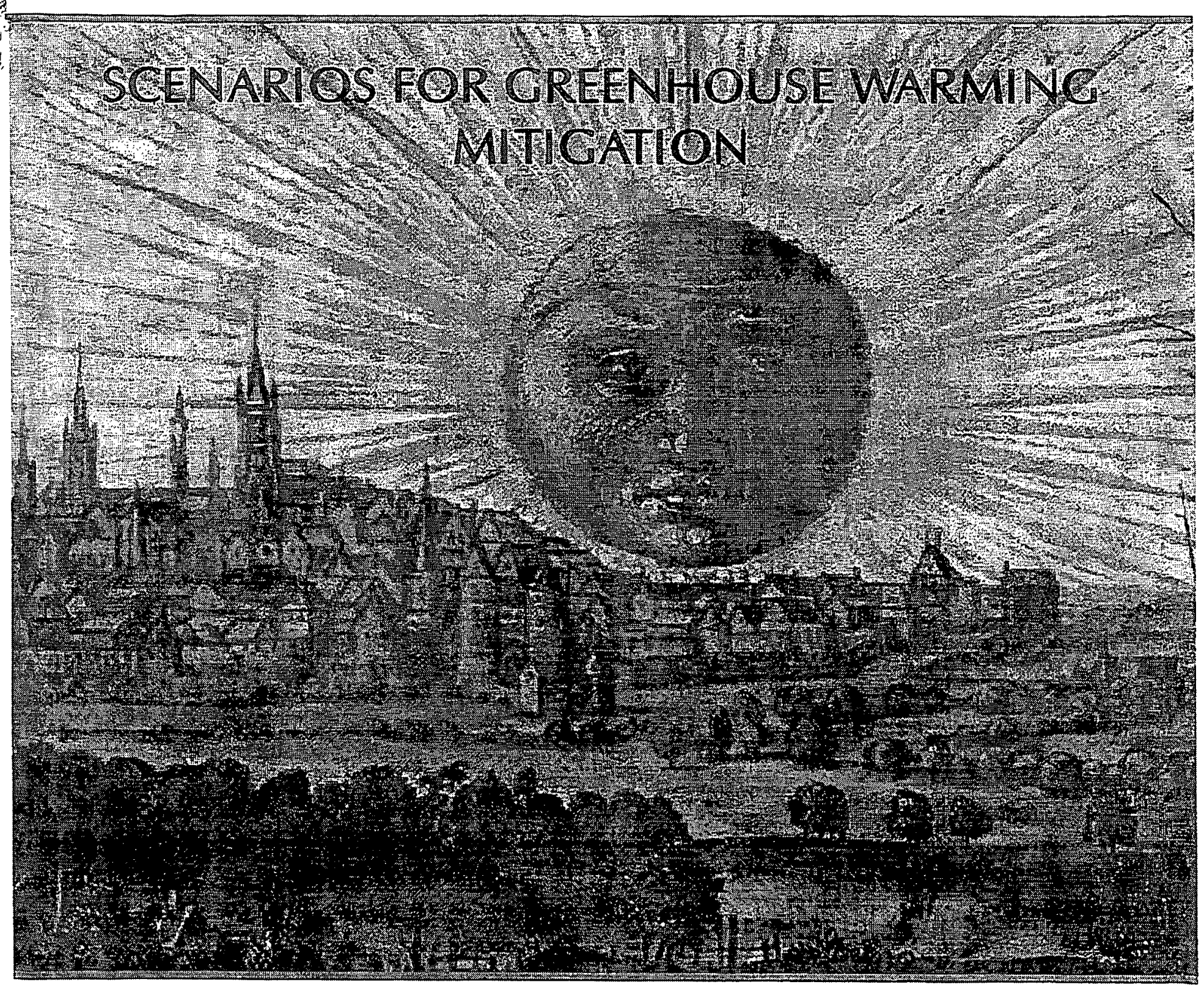

To be presented at the International Energy Agency Greenhouse Mitigation Options Conference, London, 1995 To be published in "Energy Conversion and Management"

il

siti

TEKSTER fra ROSKILDE UNIVERSITY • INSTITUTE 2 FUNCTIONS IN EDUCATION, RESEARCH AND APPLICATIONS

ENERGY \& ENVIRONMENT GROUP 
ROSKILDE UNIVERSITY, P O BOX 260, DK-4000 ROSKILDE, DENMARK

TEL: (+45) 46757711 , FAX: (+45) 46755 065, TELEX 43158.

INSTITUTE OF STUDIES IN MATHEMATICS AND PHYSICS, AND THEIR FUNCTIONS

IN EDUCATION, RESEARCH AND APPLICATION.

8. July 1995

SCENARIOS FOR GREENHOUSE WARMING MITIGATION

by Bent Sørensen

IMFUFA text no. 300, 8 pages.

ISSN 01066242

\begin{abstract}
Four global scenarios of energy provision are considered, all of which have zero net emissions of greenhouse gases. The scenarios assume the same demand for energy services and a high degree of emphasis on energy efficiency. The supply options are clean fossil fuels, safe nuclear power, centralised or decentralised renewable energy, respectively. The scenarios provide an "existence proof" of greenhouse mitigation options, but otherwise are very different, in terms of energy infrastructure and presumably cost. Detailed estimates of environmental costs and regional setup including trade patterns have not yet been fully carried out, and the results are thus preliminary.
\end{abstract}




\title{
SCENARIOS FOR GREENHOUSE WARMING MITIGATION
}

\author{
BENT SøRENSEN \\ Roskilde University, Institute 2 \\ P.O.Box 260, DK-4000 Roskilde, Denmark
}

\begin{abstract}
Four global scenarios of energy provision are considered, all of which have zero net emissions of greenhouse gases. The scenarios assume the same demand for energy services and a high degree of emphasis on energy efficiency. The supply options are clean fossil fuels, safe nuclear power, centralised or decentralised renewable energy, respectively. The scenarios provide an "existence proof" of greenhouse mitigation options, but otherwise are very different, in terms of energy infrastructure and presumably cost. Detailed estimates of environmental costs and regional setup including trade patterns have not yet been fully carried out, and the results are thus preliminary.
\end{abstract}

\section{INTRODUCTION}

The IPCC Working Group 2 has broadly identified options for mitigation of the greenhouse warming associated with extrapolating the current energy supply structure [1], but it also deplores the absence of well thought-out global scenarios that combine the individual options into a credible picture of the overall future energy supply. The present contribution is a presentation of an ongoing project aimed at supplying such detailed scenarios, and it gives preliminary results for the main characteristics of four key scenarios, each of which is extreme in using basically only one type of energy supply. Actual energy policies may of course select any mix of the base scenarios. However, these are useful in discussing the characteristics as well as the impacts of any combination.

\section{BASIC ASSUMPTIONS AND DEMAND MODEL}

The scenario year is 2050 , in order to allow for a complete replacement of all equipment (except some buildings) with the best technology available. This implies a uniform assumption of high conversion efficiencies, right to the final conversion of energy into the service or product demanded, for all the scenarios. Table 1 gives the assumptions regarding population and end-use energy demand. The population estimates are from the World Bank [2] and the 2050 values correspond to the assumptions of high welfare and economic activity. The end-use energy estimates are the minimum amounts of energy, that could deliver the service actually demanded, using the best method and conversion equipment known today. The goal, which in 2050 has not been achieved in all regions, is based on a basic and derived needs analysis made previously [3]. It assumes that the Earth will continue to be populated by a mixture of audacious and concerned citizens. The audacious citizens are risk takers, who want to implement new ideas quickly and not to deal with negative impacts until they show. The concerned citizens worry about the environment and possible side effects of human activities, so they want to move very cautiously ahead. The scenario growth in demand satisfaction between 1990 and 2050 is seen to be 2-3 times higher than the corresponding growth between 1930 and 1990, which indicates that very challenging assumptions regarding future economic and social development have been invoked. The regional distribution of energy supply will only appear after the energy system analysis has been carried out, but it is already clear, that it will be substantially different from the IPCC and WEC scenarios [1], due to the analysis made of the detailed composition of the energy use at the end-user (a feature that is deplorably missing from most current international statistics).

Figure 1 gives the 1990 energy supply and conversion structure in condensed form. Out of the $10 \mathrm{TWy} / \mathrm{y}$ primary energy, about $77 \%$ is delivered to the final user. This is reduced to about $50 \%$ taking into account some obvious losses in end-use conversion [4,5], but further down to $10 \%$, when the above definition of energy service is used. It is thus clear, that the most significant area for improvement is in the processes taking place at the end-user. Significantly better design of end-use supply systems and better technical efficiencies of end-use equipment is thus a common assumption for all the scenarios. At unchanged demand, this alone would reduce the necessary energy supply by about a factor of four, but it will have to be folded with activity increase and alterations in the system setup, between now and 2050.

\section{THE CLEAN FOSSIL (CF) SCENARIO}

The clean fossil fuel scenario assumes that by 2050 , fossil energy will be used without emission of carbon dioxide. Either the fuel has been transformed into hydrogen or $\mathrm{CO}_{2}$ is captured and removed from the flue gases. 
Hydrogen can be produced from natural gas using the chemical reaction energy to form the steam required, or from coal by the water-to-gas shift reaction [6,7]. Flue gas cleaning lower the efficiency of power plants, but is technically feasible [8]. The captured $\mathrm{CO}_{2}$ would subsequently be stored in abandoned natural gas fields or other types of natural or artificial caverns [1]. The total energy system is shown in Figure 2. The hydrogen is used directly as a fuel in industry, or in fuel cell plants producing electricity and if feasible also heat, to be distributed by appropriate power and district heating lines. Half the transportation sector is run on electric vehicles (with batteries if not on tracks), the other half on hydrogen, using small size fuel cells for increased efficiency. Heat pumps are used to provide low-temperature heat, in addition to the district heating. Oil is only used as a feedstock for non-energy purposes, and the chief source of energy is coal. For natural gas the currently identified resources will only last to around 2030 at the rate of usage assumed, and although additional resources may be turned into commercial reserves, this scenario has to be considered transitional. However, a shift towards only relying on coal would prolong the transitional periods to several hundred years.

Table 1. Population (million) and end-use energy (W/cap), the 2050 values used in all scenarios

\begin{tabular}{||l|r|r|r||r|r|r|r||}
\hline & \multicolumn{3}{|c|}{ Pop. } & \multicolumn{3}{c||}{ energy } \\
\hline Region & 1930 & \multicolumn{1}{|c|}{1990} & 2050 & 1930 & 1990 & 2050 & goal \\
\hline \hline USA, Canada & 132 & 265 & 310 & 800 & 900 & 1100 & 1100 \\
\hline W Europe, Jap., Astr. & 362 & 545 & 610 & 700 & 900 & 1100 & 1100 \\
\hline $\begin{array}{l}\text { E Europe, former } \\
\text { Soviet, Middle East }\end{array}$ & 240 & 530 & 880 & 200 & 380 & 800 & 1200 \\
\hline Latin America, SE Asia & 660 & 1860 & 4000 & 100 & 115 & 700 & 1000 \\
\hline China, rest of Asia & 442 & 1190 & 2000 & 60 & 60 & 700 & 1100 \\
\hline Africa & 152 & 610 & 2000 & 60 & 40 & 200 & 900 \\
\hline \hline World (average energy) & 2000 & 5000 & 9800 & 251 & 248 & 644 & 1026 \\
\hline
\end{tabular}

\section{THE SAFE NUCLEAR (SN) SCENARIO}

The safe nuclear scenario addresses the main objections to current nuclear power technologies: proliferation issues, large nuclear accidents and long-term storage of waste. To avoid proliferation of fissile material such as plutonium, spent fuel from reactors would be recycled to an accelerator breeder rather than being reprocessed [9]. One thereby reduces the fuel input by a factor of three, while also avoiding at least part of the proliferation problem. The reactors themselves can be made more safe in two ways. One is to reduce the size so much that core melt accidents almost certainly can be contained. This involves maximum unit sizes of 50-100 MW. The other method is to make the conventional light water reactor inherently safe, by enclosing the reactor core of a pressurized water reactor (PWR) within a vessel of boronated water, that will flood the core if pressure is lost, as there is no barrier between the core and the pool of water, that in the absence of pressure in the primary system will shut the reactor down and continue to remove heat from the core by natural circulation. It is calculated that in an accident situation, replenishing of cooling fluid can be done at weekly intervals (in contrast to hours or less for current light water reactor designs) [10]. Finally, as regards nuclear waste, the most long-lived components could be removed by transmutation. At present, the only scheme for doing this would involve a liquid metal breeder reactor [11], which does not fulfill the demand for inherent safety. For this reason, the transmutation step is just indicated in the energy system diagram shown in Figure 3, but not actually used. On the other hand, breeders seem to be required in any scenario of this kind, due to the resource aspect. Even with the factor 3 accelerator breeding, presently identified resources would at the scenario usage rate become depleted in 9 years, and only the true breeding at over a factor 60 will make this scenario sustainable for even the lifetime of the equipment involved.

\section{THE DECENTRALISED RENEWABLE ENERGY (DRE) SCENARIO}

The renewable energy scenario depicted in Figure 4 is similar to one constructed earlier for Denmark [12] and under construction for the European Union [13]. It uses the currently available low-temperature solar thermal, wind and biogas technologies, as well as anticipated photovoltaic technology that is similar to the current one, 
but affordable for large-scale power production. As in the fossil scenario, fuel cell technology is assumed to be available, as well as technology for producing hydrogen from biomass (gasification plus shift reaction as for coal) [14]. For the non-electrified part of the transportation sector, liquid biofuels such as methanol are introduced $[6,15]$, in order to minimize the change from current gasoline use. The large share of bioenergy ensures that there is backup for the variable renewable energy sources (solar radiation and wind), notably through active storage of either primary biomass or of biogas and hydrogen in caverns, in combination with the flexibility offered by use of reversible fuel cells instead of conventional power stations. This allows surplus wind and solar cell produced electricity to be converted to a storable fuel, whereas in the transportation sector, the liquid biofuels play this role. In the heating sector, some of the solar heat is stored in (communal size) heat stores connected to district heating lines. However, district heating only makes sense in regions with fairly high heat use density, so in other regions, a backup for the solar panels is provided by biogas and by having heat pumps available.

\section{THE CENTRALISED RENEWABLE ENERGY (CRE) SCENARIO}

The amount of biomass used in the DRE scenario is large (almost as large as in the IPCC high-biomass scenario [1]) and it requires partly an integrated food and energy production (using residues for biogas and returning fertilizer), partly a biomass to hydrogen and methanol path that may require dedicated bioenergy growth (wood plantations etc.). Only in some parts of the world is this possible, and generally, one has to ensure not only a sustainable energy production, but also a sustainable food production. This involves a number of issues, such as ecological farming (without pesticides) and altered animal and vegetable production ratios [12]. Only the detailed analysis of DRE scenarios will determine, if such sustainability is possible. It is therefore explored here, if a scenario with considerably less biomass use would be feasible. The methanol production is removed and the biomass gasification reduced. The additional energy is obtained from photovoltaics. The decentralized potential on building roofs and facades is considered exploited already in the DRE scenario, so the additional solar cell installations are assumed to be central plants located on infertile lands (deserts etc.). The price for this arrangement is considerable intercontinental power transmission, but losses are still smaller than in the liquid biofuel production. A detailed analysis is needed in order to ensure that the storage capacity in this scenario is sufficient. A positive feature is that the solar electricity production is likely to be higher and more stable in the mostly equatorial desert areas considered, and that the increased power production per unit collector area may pay for the additional structure and transmission equipment.

\section{COST ESTIMATES}

In the fossil scenario, decarbonization of fuels is estimated to increase costs less than $50 \%$, whereas removal from flue gases is somewhat more expensive. The cost of $\mathrm{CO}_{2}$ deposition is little known, but probably affordable for natural gas wells. Totally, the energy cost may rise to 2-3 times the present one, which may match the externality cost of greenhouse warming damages [16]. For the nuclear scenario, entirely new techniques are brought in at unknown or high cost [11]. Adding the uncertainty of the breeder reactor that seems to be required for this scenario, the preliminary conclusion would be that it is not a viable option for introduction before 2050 . The renewable energy scenarios incorporate wind and biogas systems with costs only slightly higher than current system costs, and also photovoltaic panels, for which considerable (but envisaged) cost reductions have to become realised. These scenarios also include increased use of energy storage or demand management, at a corresponding cost. For the decentralised scenario, the cost of biofuels has to be considered (currently about twice the present energy price [15]), while for the centralised one, the cost of long-distance power transmission is crucial and probably requires new technologies of lower cost than current ones. The detailed cost and externality estimates will have to be performed in order to complete this discussion.

\section{CONCLUSIONS}

As the scenarios presented here are preliminary and the detailed region by region analysis still has to be done, one should be careful in attaching too much importance to the evaluation of the scenarios. It does appear that the nuclear scenario will have serious problems and probably is not realisable within the 60 year time period considered. Also the centralized renewable energy scenario depends on unproven technology advances (in transmission technology), or will become very expensive. Only the clean fossil and decentralized renewable scenarios seem to be technically feasible and at costs than may be within the range of "fair market" estimates based on present energy prices (minus subsidies and taxes) but plus externality costs, of which the very uncertain greenhouse warming costs are the most significant (estimated at over $0.1 \mathrm{ecu} / \mathrm{kWh} \mathrm{[16],} \mathrm{mostly} \mathrm{due} \mathrm{to} \mathrm{the} \mathrm{effects}$ of extreme events on developing countries). 


\section{REFERENCES}

1. IPCC Second Assessment Report, Working Group 2 (to be published) (1995).

2. World Bank, World Population Projections (K Zachariah and M Wu). Baltimore (1988).

3. B Sørensen, pp. 35-74 in "Renewable energy and local production". Danish Center for Renewable Energy (1988).

4. B Sørensen, Energy, vol. 6, pp. 293-303 (1981); vol. 7, pp. 783-799 (1982).

5. N Nakicenovic et al., Energy, vol. 18, pp. 401-609, and IIASA database (1993).

6. J Jensen and B Sørensen, Fundamentals of Energy Storage. Wiley, New York (1984).

7. R Williams, Fuel decarbonization for fuel cell applications and sequestration of the separated $\mathrm{CO} 2$. (preprint) (1995).

8. C Hendriks, Thesis. Dept. Science, Technology \& Society. Utrecht University (1994).

9. P Grand, Nature, vol. 278, pp. 693-696 (1979).

10. R Klueh, New Scientist, 3. April, pp. $41-45$ (1986); K. Hannerz, Nucl. Eng. Int., Dec., p. 41 (1983).

11. T Pigford, pp. 97-99 in "Transmutation as a waste management tool", Conf. Proc. (1991).

12. B Sørensen et al., Renewable energy system of the future. (in Danish). Technology Council, Copenhagen (1994).

13. O Hohmeyer, H Lehman, B Sørensen, et al., Long-term integration of renewable energy into the European energy system. EC APAS project internal reports (1995).

14. R Williams, E Larson, R Katofsky, J Chen, Methanol and hydrogen from biomass for transportation. (preprint) (1995).

15. European Commission, DG XII, Biofuels. Report EUR 15647 EN, Brussels (1994).

16. B Sørensen, The role of life-cycle analysis in risk assessment, Int. J. of Environment and Pollution (to be published).

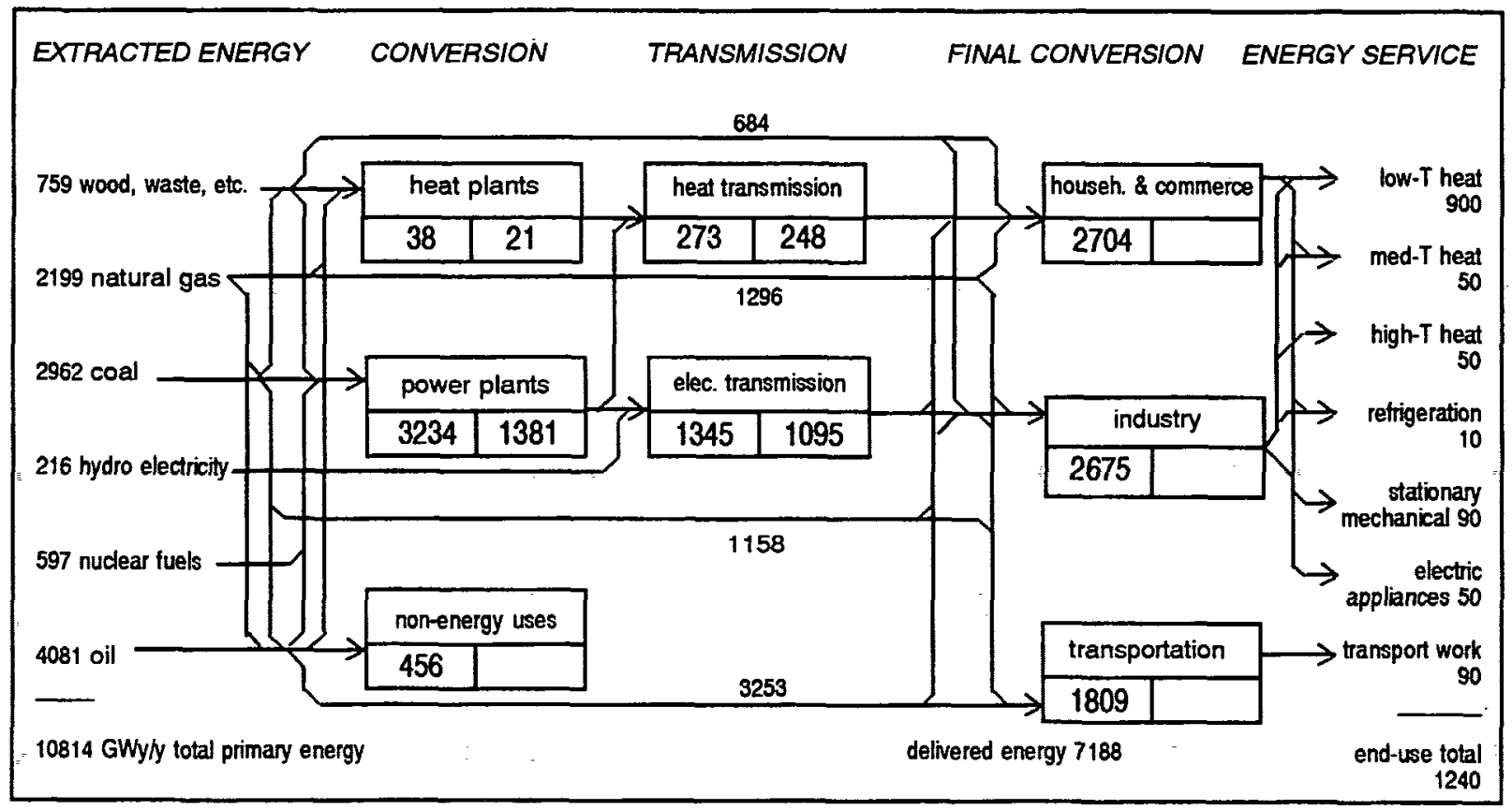

Figure 1. The 1990 global energy system (GWy/y). 


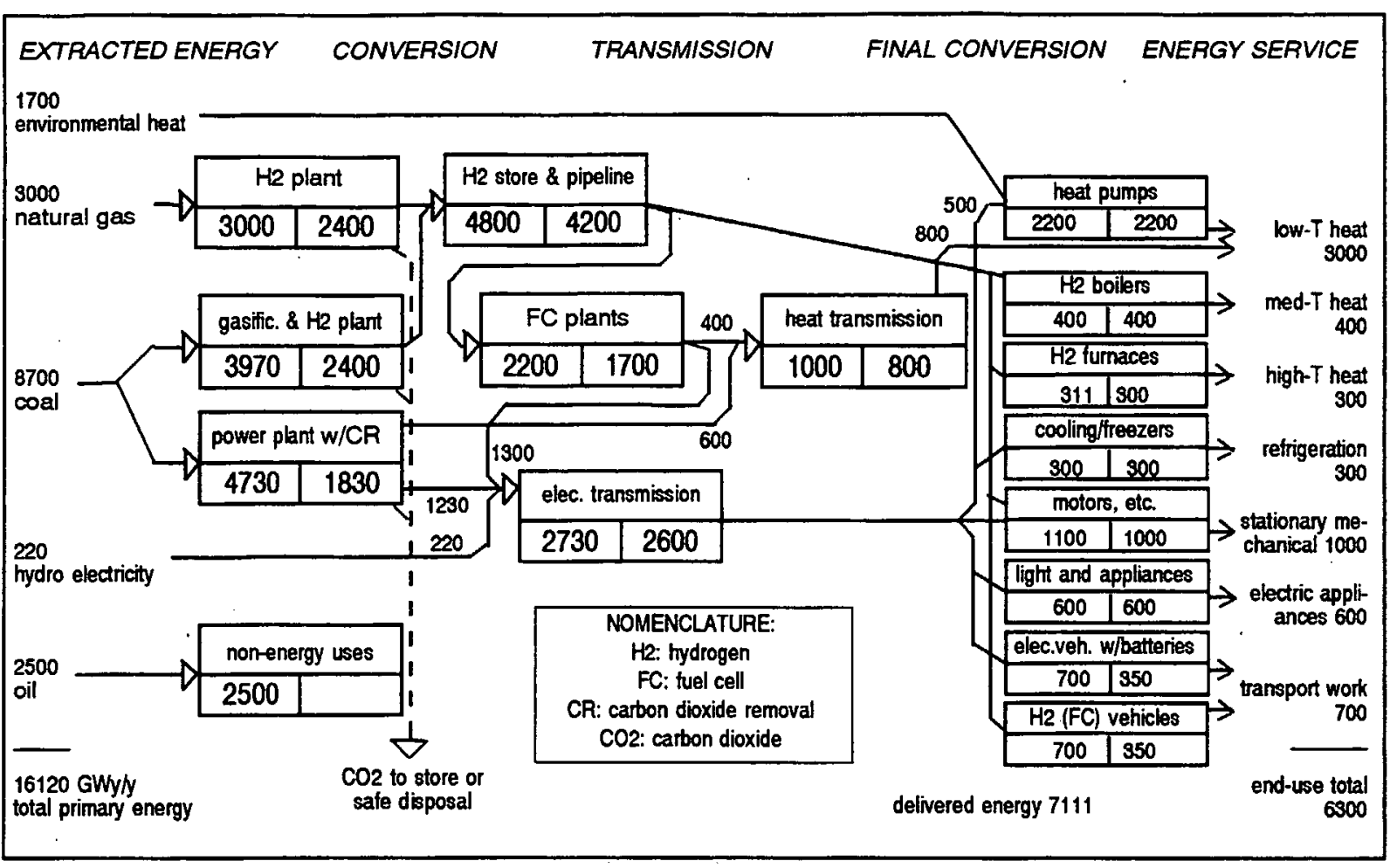

Figure 2. A 2050 clean fossil energy scenario $(\mathrm{GWy} / \mathrm{y})$.

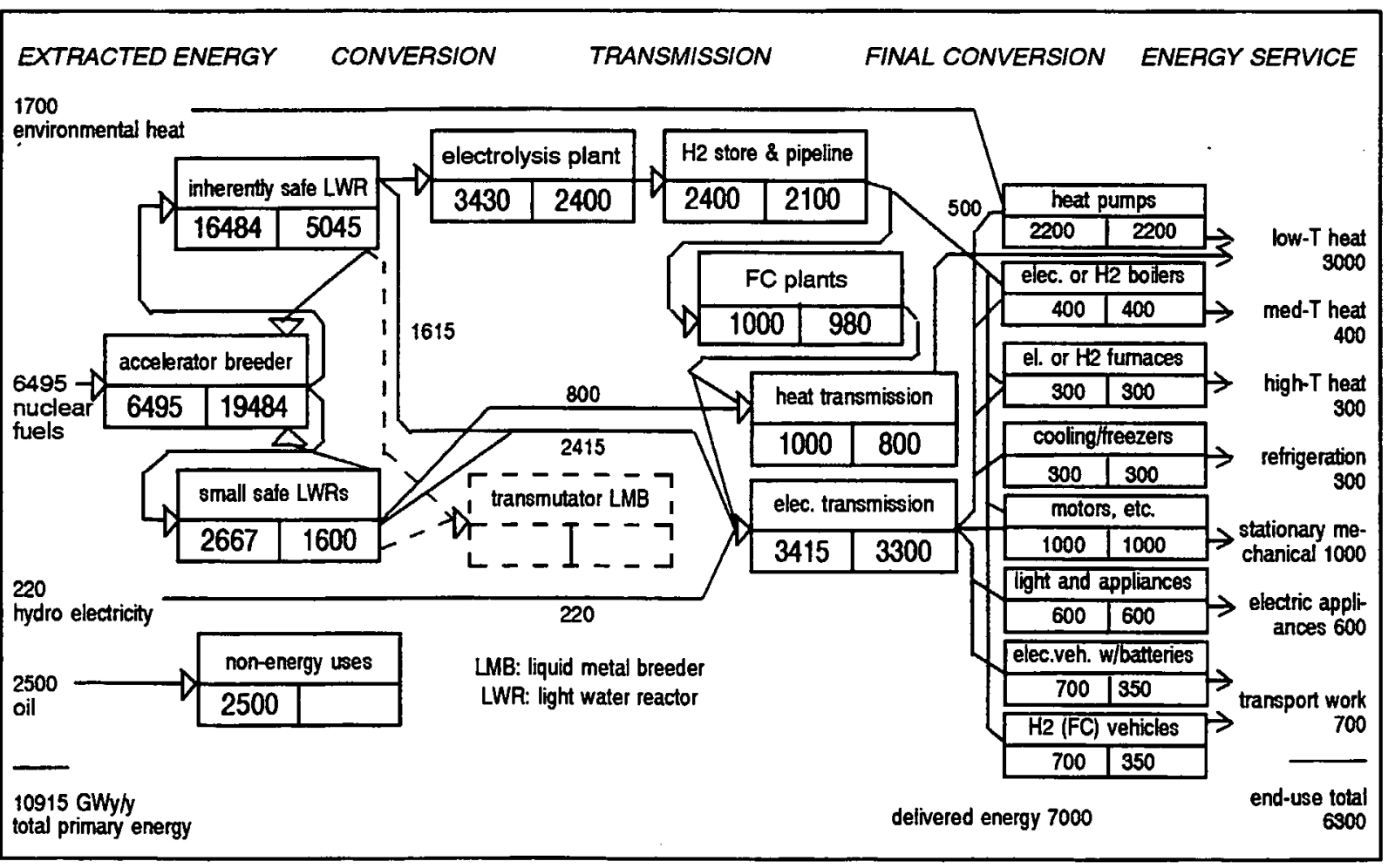

Figure 3. A 2050 safe nuclear energy scenario ( $G W y / y)$. 


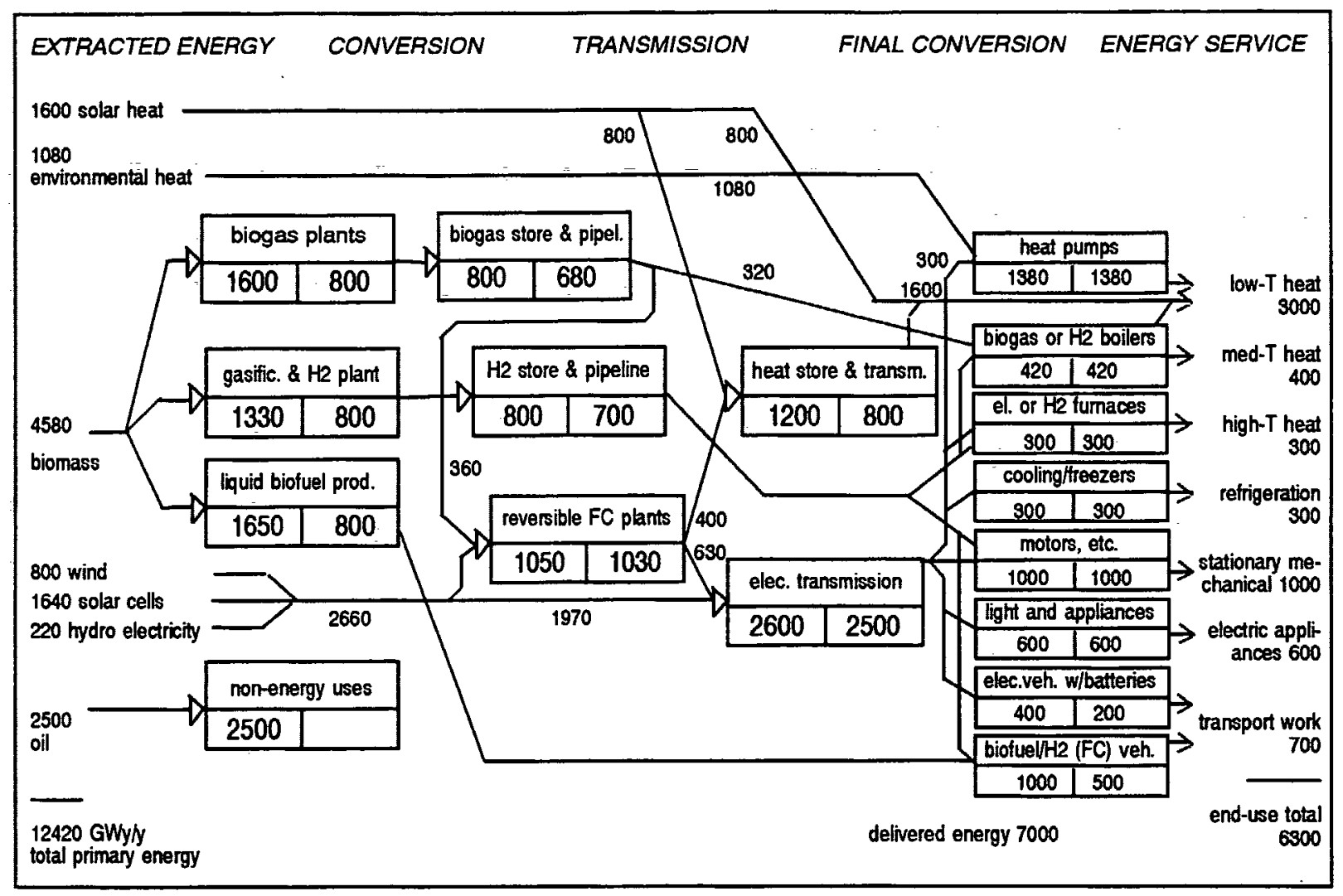

Figure 4. A 2050 decentralized renewable energy scenario (GWy/y).

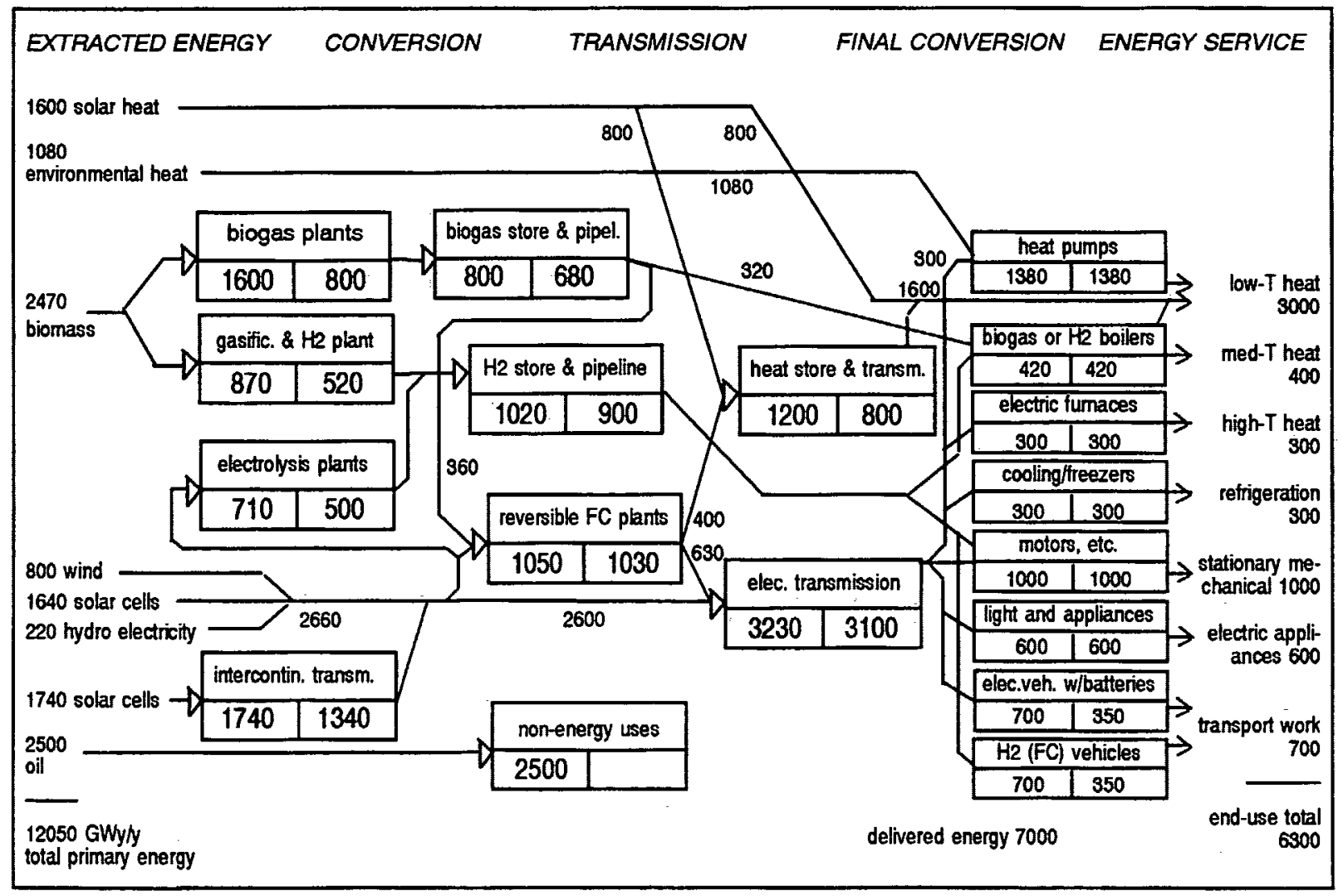

Figure 5. A 2050 centralized renewable energy scenario ( $G W y / y)$. 
227/92 "Computersimulering og fysik"

af: Per M.Hansen, Steffen Holm,

Peter Maibom, Mads K. Dall Petersen,

Pernille Postgaard, Thomas B.Schroder. Ivar P. Zeck

Vejleder: Peder Voetmann Christiansen

Liste over tidligere udkomne tekster

tilsendes gerne. Henvendelse herom kan

ske til IMHUFA's sekretariat

tif. 46757711 lokal 2263
$228 / 92$ "Teknologi og historie"

Fire artikler af

Mogens Niss, تiens Høyrup, Ib Thiersen, Hans Hedal

$229 / 92$ "Nasser af information uden betydning" En diskussion af informationsteorien i. Tor Nørietranders" "Mæik Verden" og en skitse til et alternativ basserei på andenordens kybernetik og semiotik. af: Søien Brier

217/92 "Two papers on APPLICATIONS AND MODELLING IN THE MATHEMATICS CURRTCUIUM"

by: Mogens Niss

218/92 "A Three-Square Theorem"

by: Lars Kadison

$219 / 92$ "RUPNOK - stationær strømning $i$ elastiske rør" af: Anja Boisen, Karen Birkelund, Mette Olufsen Vejleder: Jesper Larsen

220/92 "Autonatisk diagnosticering i digitale kredsløb" af: Bjørn Christensen, Ole Møller Nielsen Vejleder: Stig Andur Pedersen

221/92 "A BUNDLE VALUED RADON TRANSFORM, WITH APPLICATIONS TO INVARIANT WAVE EQUATIONS"

by: Thomas P. Branson, Gestur Olafsson and Henrik Schlichtkrull

222/92 On the Representations of some Infinite Dimensional Groups and Algebras Related to Quantum Physics by: Johnny T. Ottesen

223/92 THE FUNCTTONAL DETERMINANT

by: Thomas P. Branson

224/92 UNIVERSAL AC CONDUCTIVTTY OF NON-METALLIC SOLIDS AT LOW TEMPERATURES

by: Jeppe C. Dyre

225/92 "HATMODELLEN" Impedansspektroskopi i ultrarent en-krystallinsk silicium

af: Anja Boisen, Anders Gorm Larsen, Jesper Varmer, Johannes K. Nielsen, Kit R. Hansen, Peter Bøggild og Thomas Hougaard

Vejleder: Petr Viscor

226/92 "METHODS AND MODELS FOR ESTIMATTNG THE GLOBAL CIRCULATTON OF SELECTED EMISSIONS FROM ENERGY CONVERSTON"

by: Bent Sorensen
"Vinklens tredeling - et klassisk problem"

et matematisk projekt af

Karen Birkelund, Bjørn Christensen vejleder: تohnny ottesen

231A/92 "Elektrondiffusion i silicium -- en matematisk model"

af: Jesper Voetmann, Karen Birkelund, Mette olufsen, Ole Møller Nielsen

Vejledere: Johnny Ottesen, H.B.Hansen

231B/92 "Elektrondiffusion i silj.cium - en matematisk model" Kildetekste: af: üesper Voetmann, Karen Birkelund, Mette olufsen, ole Moller Nielsen

Vejledere: Johnny ottesen, H.B.Hansen

232/92 "Undersøgelse om den simultane opdagelse af energiens bevarelse og isæräeles om de af Mayer, Colding, Joule og Helmholic uaførte arbejder"

af: L.Arleth, G.I.Dybkjær, M.T.Østergård Vejleder: Dorthe Posselt

233/92 "The effect of age-dependent host mortality on the dynamics of an endemic disease and

Instability in an SIR-model with agedependent susceptibility

by: Viggo Andreasen

$234 / 92$

"THE FUNCTIONAL DETERMINANT OF A FOUR-DIMENSCONAL BOUNDARY VALUE PROBLEM"

by: Thomas P. Branson and Peter B. Gilkey

235/92 OVERFLADESTRUKTUR OG POREUDVIKLING AF KOKS

- Modul 3 fysik projekt -

af: Thomas Jessen 
$236 a / 93$ INTRODUKTION TIL KVANTE

HALL EFFEKTEN

af: Anja Boisen, Peter Boggild

Vejleder: Peder Voetmann Christiansen Erland Brun Hansen

$236 b / 93$ STROMSSAMMENBRUD AF KVANTE HALL EFFEKTEN

af: Anja Boisen, Peter Bøggild

Vejleder: Peder Voetmann Christiansen Erland Brun Hansen

$237 / 93$ The Wedderburn principal theorem and Shukla cohomology

af: Lars Kadison

$238 / 93$ SEMIOTIK OG SYSTEMEGENSKABER (2)

Vektorbånd og tensorer

af : Peder Voetmann Christiansen

239/93 Valgsystemer - Modelbygning og analyse

Matematik 2. modul

af: Charlotte Gjerrild, Jane Hansen, Maria Hermannsson, Allan Jorgensen, Ragna Clauson-Kaas, Poul Lützen

Vejleder: Mogens $\mathrm{Niss}$

240/93 Patologiske eksempler.

Om sare matematiske fisks betydning for

den matematiske udvikling

af: Claus Dræby, Jørn Skov Hansen, Runa Ulsoe Johansen, Peter Meibom, Johannes Kristoffer Nielsen

Vejleder: Mogens Niss

241/93 FOTOVOLTAISK STATUSNOTAT 1

af : Bent Sørensen

$242 / 93$ Brovedligeholdelse - bevar mig vel

Analyse af Vejdirektoratets model for optimering af broreparationer

af: Linda Kyndlev, Kare Fundal, Kamma

Tulinius, Ivar Zeck

Vejleder: Jesper Larsen

243/93 TANKEEKSPERIMENTER I FYSIKKEN

Et l.modul fysikprojekt

af: Karen Birkelund, Stine Sofia Korremann

vejleder: Dorthe Posselt

244/93 RADONTRANSFORMATIONEN Oq dens anvendelse i Ci-scanning

Projektrapport

af: Trine Andreasen, Tine Guldager Christiansen. Nina Skov Hansen og Christine Iversen

vejledere: Gestur Olafsson og Jesper Larsen

$245 a+b$

/93 Time-of-Flight målinger på krystallinske

halvledere

Specialerapport

af: Linda Szkotak Jensen og Lise Odgaard Gade

Vejledere: Petr Viscor og Niels Boye Olsen

246/93 HVERDAGSVIDEN OG MATEMATIK

- LEREPROCESSER I SKOLEN

af: Lena tindenskov, Statens Humanistiske

Forskningsråd, RUC, IMFUFA
$247 / 93$ UNIVERSAL LOW TEMPERATURE AC CONDUCTIVITY OF MACROSCOPICALLY DISORDERED NON-METALS

by: Jeppe C. Dyre

$248 / 93$ DIRAC OPERATORS AND MANIFOLDS WITH BOUNDARY

by: B. Booss-Bavnbek, K.P.Wojciechowski

249/93 Perspectives on Teichmüller and the Jahresbericht Addendum to Schappacher Scholz, et al.

by: B. Booss-Bavnbek

with comments by W.Abikoff, I.Ahlfors, J.Cerf, P.J.Davis, W.Fuchs, F.P.Gardiner, J.Lost, J.-P.Kahane, R.Lohan, I.Lorch, J.Radkau and T.Soderquist

250/93 EULER OG BOLZANO - MATEMATISK ANALYSE SET I ET VIDENSKABSTEORETISK PERSPEKTIV

Projektrapport af: Anja Juul, Lone Michelsen, Tomas Højgård Jensen

Vejleder: Stig Andur Pedersen

251|93 Genotypic Proportions in Hybrid Zones

by: Ereddy Bugge Christiansen, Viggo Andreasen and Ebbe Thue Poulsen

$252 \mid 93$ MODELLERING AF TILFALDIGE FANOMENER

Projektrapport af: Birthe Friis, Lisbeth Helmgaard, Kristina Charlotte Jakobsen, Marina Mosbak Johannessen, Lotte Ludvigsen, Mette Hass Nielsen

253/93 Kuglepakning

Teori og model

af: Lise Arleth, Kåre Fundal, Nils Kruse

Vejleder: Mogens Niss

254/93 Regressionsanalyse

Materiale til et statistikkursus

af: Jørgen Larsen

$255 / 93$ TID \& BETINGET UAFHANGIGHED

af: Peter Harremoës

$256 / 93$ Determination of the Frequency Dependent Bulk Modulus of Liquids Using a Piezoelectric Spherical Shell (Preprint)

by: T. Christensen and N.B.OLsen

257/93 Modellering af dispersion i piezoelektriske keramikker

af: Pernille Postgaard, Jannik Rasmussen, Christina Specht, Mikko Dstergärd

Vejleder: Tage Christensen

258/93 Supplerende kursumateriale til

"Lineare strukturer fra algebra og analyse"

af: Mogens Brun Beefelt

259/93 STUDIES OF AC HOPPING CONDUCTION AT LOW TEMPERATURES

by: Jeppe C. Dyre

260/93 PARTITTONED MANTFOLDS AND INVARIANTS IN DJMENSTONS 2, 3, AND 4

by: B. Booss-Baumbek, K.P. Wojciechowski 
$261 ; 93$ OPGAVESAML ING

Bredde-kursus i Fysik

Eksamensopgaver fra 1976-93

$262 / 93$ Separability and the Jones Polynomial

by: Lars Kadison

263/93 Supplerende kursusmateriale til "Lineære strukturer fra algebra oq analyse" II

af: Mogens Brun Heefelt

$264 / 93$ FOTOVOLTAISK STATUSNOTAT 2 af: Bent Sørensen

265/94 SPHERICAL FUNCTIONS ON ORDERED SYMMETRIC SPACES

To Sigurdur Helgason on his sixtyfifth birthday

by: Jacques Faraut, Joachim Hilgert and Gestur olafsson

266/94 Kommensurabilitets-oscillationer i

laterale supergitre

Fysikspeciale af: Anja Boisen,

peter Bøggild, Karen Birkelund

Vejledere: Rafael Taboryski, Poul Erik

Lindelof, Peder Voetmann Christiansen

267/94 Kom til kort med matematik på

Eksperimentarium - Et forslag til en

opstilling

af: Charlotte Gjerrild, Jane Hansen

vejleder: Bernhelm Booss-Bavnbek

268/94 Life is like a sewer ...

Et projekt om modellering af aorta via en model for strømning $i$ kloakrør

af: Anders Marcussen, Anne C. Nilsson, Lone Michelsen, Per M. Hansen

Vejleder: jesper Larsen

269/94 Dimensionsanalyse en introduktion

metaprojekt, fysik

af: Tine Guldager Christiansen,

Ken Andersen, Nikolaj Hermann,

Jannik Rasmussen

Vejleder: Jens Højgaard Jensen

270/94 THE IMAGE OF THE ENVELOPING ALGEBRA AND IRREDUCIBILITY OF INDUCED REPRESENTATIONS OF EXPONENTIAL LIE GROUPS

by: Jacob jacobsen

271/94 Matematikken i Fysikken.

Opdaget eller opfundet

NAT-BAS-projekt

vejleder: Jens Højgaard Jensen
272/94 Tradition og fornyelse

Det praktiske elevarbejde i grmnasiets fysikundervisning, 1907-1988

af: Kristian Hoppe og Jeppe Guldager

Vejledning: Karin Beyer og Nils Hybel

273/94 Model for kort- og mellendistanceløb

Verifikation af model

af: Lise Fabricius Christensen, Helle Pilemann, Bettina Sorensen

Vejleder: Mette Olufsen

274/94 MODEL 10 - en matematisk model af intravenose anæstetikas farmakokinetik

3. modul matematik, forår 1994

af: Trine Andreasen, Bjørn Christensen, Christine Green, Anja Skjoldborg Hansen. Lisbeth Helmgaard

Vejledere: Viggo Andreasen \& Jesper Larsen

275/94 Perspectives on Teichmüller and the Jahresbericht 2nd Edition

by : Bernhelm Booss-Bavnbek

276/94 Dispersionsmodellering

Projektrapport 1. modul

af: Gitte Andersen, Rehannah Borup, Lisbeth Fris, Per Gregersen, Kristina Vejrø

Vejleder: Bernhelm Booss-Bavnbek

277/94 PROJEKTARBEJDSPEDAGOGIK - Om tre tolkninger af problemorienteret projektarbejde

af: Claus Flensted Behrens, Frederik Voetmann Christiansen, Jørn Skov Hansen, Thomas Thingstrup

Vejleder: Jens Hojgaard Jensen

278/94 The Models Underlying the Anaesthesia Simulator Sophus

by: Mette Olufsen(Math-Tech), Finn Nielsen (RISø National Laboratory), Per Føge Jensen (Herlev University Hospital), Stig Andur Pedersen (Roskilde University)

279/94 Description of a method of measuring the shear modulus of supercooled liquids and a comparison of their thermal and mechanical response functions.

- af: Tage Christensen

280/94 A Course in Projective Geometry by Lars Kadison and Matthias T. Kromann

281/94 Modellering af Det Cardiovaskulære System med Neural Pulskontrol

Projektrapport udarbejdet af :

Stefan Frello, Runa Ulsøe Johansen, Michael Poul Curt Hansen, Klaus Dahl Jensen Vejleder: Viggo Andreasen

282/94 Parallelle algoritmer

af: Erwin Dan Nielsen, Jan Danielsen, Niels Bo Johansen 
283/94 Grænser for tilfældighed

(en kaotisk talgenerator)

af: Erwin Dan Nielsen og Niels Bo Johansen

284/94 Det er ikke til at se det, hvis man ikke lige ve' det!

Gymnasiematematikkens begrundelsesproblem

En specialerapport af Peter Hauge Jensèn og Linda Kyndlev

Veileder: Mogens Niss

285/94 Slow coevolution of a viral pathogen and its diploid host

by: Viggo Andreasen and

Freddy B. Christiansen

286/94 The energy master equation: A low-temperature approximation to Bässler's random walk model

by: Jeppe C. Dyre

287/94 A Statistical Mechanical Approximation for the Calculation of Time Auto-Correlation Functions by: Jeppe C. Dyre

288/95 PROGRESS IN WIND ENERGY UTILIZATION by: Bent Sørensen

289/95 Universal Time-Dependence of the Mean-Square Displacement in Extremely Rugged Energy Landscapes with Equal Minima

by: Jeppe C. Dyre and Jacob Jacobsen

290/95 Modellering af uregelmassige bolger Et 3.modul matematik projekt

af: Anders Marcussen, Anne Charlotte Nilsson, Lone Michelsen, Per Mørkegaard Hansen

Vejleder: Jesper Larsen

291/95 1st Annual Report from the project LIFE-CYCLE ANALYSIS OF THE TOTAL DANISH ENERGY SYSTEM

an example of using methods developed for the OECD/IEA and the US/EU fuel cycle externality study

by: Bent Sørensen

292/95 Fotovoltaisk Statusnotat 3

af: Bent Sørensen

293/95 Geometridiskussionen - hvor blev den af?

af: Lotte Ludvigsen \& Jens Frandsen

Vejledır: Anders Madsen

294/95 Universets udvidelse et metaprojekt

Af: Jesper Duelund og Birthe Friis

Vejleder: Ib Lundgaard Rasmussen

295/95 A Review of Mathematical Modeling of the Controled Cardiovascular System

By: Johnny T. Ottesen
296/95 RETIKULER den klassiske mekanik

af: Peder Voetmann Christiansen

$297 / 95$ A fluid-dynamical model of the aorta with bifurcations

by: Mette Olufsen and Johnny ottesen

298/95 Mordet på Schrödingers kat - et metaprojekt om to fortolkninger af kvantemekanikken

af: Maria Hermannsson, Sebastian Horst, Christina Specht

Vejledere: Jeppe Dyre og Peder Voetmann Christiansen

299/95 ADAM under figenbladet - et kig på en samfundsvidenskabelig matematisk model

Et matematisk modelprojekt

af: Claus Dræby, Michael Hansen, Tomas Højgård Jensen Vejleder: Jørgen Larsen

300/95 Scenarios for Greenhouse Warming Mitigation by: Bent Sørensen 